\title{
Determining Long-Term Trends of Four Fast-Eutrophicated Lakes in China and Finland
}

\author{
Mengna Liao ${ }^{1,2,3}, \mathrm{Ge} \mathrm{Yu}^{1,2}$, Anne-Mari Ventelä ${ }^{4} \&$ Xuhui Dong ${ }^{1,2,5}$ \\ ${ }^{1}$ Nanjing Institute of Geography \& Limnology, Chinese Academy of Sciences, Nanjing, China \\ ${ }^{2}$ State Key Laboratory of Lake Science and Environment, Nanjing, China \\ ${ }^{3}$ University of Chinese Academy of Sciences, Beijing, China \\ ${ }^{4}$ Pyhäjärvi Institute, Kauttua, Finland \\ ${ }^{5}$ Aarhus Institute of Advanced Studies, Høegh-Guldbergs Gade 6B, Aarhus C, Denmark \\ Correspondence: Ge Yu, State Key Laboratory of Lake Science and Environment, Nanjing Institute of \\ Geography \& Limnology, CAS, Nanjing, 210008, China. Tel: 86-025-8688-2141. E-mail: geyu@niglas.ac.cn
}

Received: October 4, 2015 Accepted: November 5, 2015 Online Published: December 15, 2015

doi:10.5539/jas.v8n1p39 URL: http://dx.doi.org/10.5539/jas.v8n1p39

\begin{abstract}
Lake eutrophication has increased in pace in recent decades and has caused serious environmental problems However, the development trends have not been fully determined as it is difficult to recognize complex effects emanating from both climate and human mechanisms. China has many lakes in different trophic stages, which represent three developing stages from forest- to agriculture-, and then to urban-lake, typically in Lakes Lugu, Taibai, and Taihu. To determine long-term water quality trends, the three lakes were chosen for statistic analysis on dominant effects on the diatom-inferred nutrient changes, and to undertake dynamic modelling regarding climate-controlled nutrient changes. The results indicate the significant turning points of water quality in Lakes Lugu, Taibai and Taihu occurring in the 1990s, 1950s and 1940s respectively, which were effected from human activities by increases in tourism, farming and urbanization respectively. Water quality changes in Lakes Lugu, Taibai and Taihu captured $68.4 \%, 54.9 \%$, and $86.0 \%$ of the temperature variations before the turning points. The anthropogenic impacts explained $84.0 \%, 96.4 \%$ and $96.0 \%$ of the water quality variations after the turning points, where the sharp change of water quality by human activity has played an accelerated effect on the gentle change of temperature. Compared with the 4 phases of water quality development in Pyhäjärvi Lake (SW Finland), Lakes Lugu and Taibai have experienced the $1^{\text {st }}$ and $2^{\text {nd }}$ phases, and Taihu has experienced from the $2^{\text {nd }}$ to $3^{\text {rd }}$ phases during the last 150 years. Phase 4 has not occurred in the three lakes, but it is a key period during the eutropication we need to pay attentions.
\end{abstract}

Keywords: lake water quality, long-term trends, climate change, human impact, three Chinese lakes, referenced Finish lake, statistic analysis, dynamic model

\section{Introduction}

In natural systems, eutrophication is a nutrient-enhanced process in a timescale of several hundred years (Kalff, 2002). However, the process can be dramatically accelerated by intensive human disturbances, which will endanger the structures and functions of lake ecosystems (Carpenter et al., 1995; Howarth et al., 2000; Qin, Xu, \& Dong, 2011). Nowadays, many lakes in China have been eutrophicated or reveal euthrophic trends due to excessively development and using lake and catchment resources (e.g. Dong et al., 2008; Liu et al., 2007; Wu, Huang, Zeng, Schleser, \& Battarbee, 2007). Changes in lake water quality influenced by human activity have been recognized as a progressive process from the original forest-type lake with primary vegetation types to the agriculture-type lake strongly influenced by tillage practices, and finally to the urban-type lake characterized by industrialization and urbanization (e.g. Fritz, 1989; Rasmussen, 2005; Yu, Xue, Lai, Gui, \& Liu, 2007). To analyze the processes of lake water quality within different developmental stages, such as changes in forest-agricultural-urban lakes, can provide a more comprehensive perspective to understand lake development but there have been few study in China (Yang et al., 2010).

There are 683 lakes with an area greater than $10 \mathrm{~km}^{2}$ in China (Ma et al., 2011). In these different trophic level lakes, some can be typically represented by the three types from forest lake to agriculture lake, and then to urban 
lake. Lugu Lake is a remote and isolated area in southwestern China with a low-level economy and weak human activity, and the forest covers $68.9 \%$ of the catchment area (Dong et al., 2008). The water was measured in an oligotrophic stage and the water quality is very good (Zhang, 2014). Tillage practice has become the major economic activity in eastern China, such as in the catchment of Taibai Lake. $71.4 \%$ of the area is farming land (Liu et al., 2007), which represents an agriculture-lake type. Northern Taihu Lake catchment, located in the east of China is a densely populated and highly economically developed area. It covers $36,500 \mathrm{~km}^{2}$ in the catchment, only $0.38 \%$ of the national territory area, but holds $4.2 \%$ of the total population and contributes $11 \%$ of the Gross Domestic Product in China (Xie, Yu, \& Zhang, 2001). Thus, it is a typical urban-lake type. In comparison to the three Chinese lakes mentioned above, the water quality of Pyhäjärvi Lake in SW Finland not only had experienced changes from oligotrophic condition to eutrohication, but also experienced water quality recovering (Ventelä et al., 2015). Therefore the history of water quality changes in Pyhäjärvi Lake can provide a reference for comparing the developments of Chinese lakes' water quality. Considering Chinese lakes in different trophic stages are differentially influenced by climatic and anthropogenic impacts, three Chinese lakes (Lakes Lugu, Taibai and Taihu) were chosen to study the forest-agricultural-urban lakes in eutrophication processes.

A comprehensive understanding of lake water quality changes must rely on long-term monitoring (Degobbis et al., 2000; Sayer, Davidson, Jones, \& Langdon, 2010). However, it is almost impossible to find records longer than 50 year records in China, and this is so for the three lakes. For this reason, a paleolimnological approach using diatom fossils was introduced in this study, which has proved useful for analyzing changes of lake water quality history (e.g. Harris \& Vollenweider, 1982; Levine et al., 2012; Luoto \& Ojala, 2014; Smol \& Douglas, 1996), because among paleolimnological multi-proxies the diatom fossil is a practical and workable indicator in reconstructing the past lake water quality (e.g. Anderson, 1993; Chen, Yang, Dong, \& Liu, 2011; Dong et al., 2008; Hall, Leavitt, Smol, \& Zirnhelt, 1997). However, the reconstruction based on diatom analysis can hardly distinguish anthropogenic impact from natural influence and is unable to estimate the contributions of different factors. For this reason, a nutrient dynamic model was constructed in the present study to simulate lake nutrient changes under natural conditions, by setting climate boundaries and initial human-influence conditions.

In this paper, based on the four-lake water quality changes analyzed by diatom-inferred nutrient reconstructions, we used Principal Component Analysis (PCA) to diagnose the major change signals of lake water quality controlled by both climate and human activity. Meanwhile, a lake nutrient dynamic model was constructed to simulate nutrient changes under the climate conditions. By comparing the two-approach results, we attempted to distinguish the impacts of climate only and overlaying human activity. Finally, to compare with Pyhäjärvi Lake trends, we figured out respective stages of the three Chinese lakes, and analyzed the potential trends of their water quality.

\section{Study Site}

In this study, three lakes of Lugu, Taibai and Taihu (Figure 1) were chosen respectively as typical cases of forest-, agriculture- and urban-type lakes according to the developing stages and the strengths of human activities in the catchments.

(1) Lugu Lake $\left(27.27^{\circ} \mathrm{E}, 100.78^{\circ} \mathrm{N}, 2690.75 \mathrm{~m}\right.$ a.s.l) is located in the upper reach of the Yangtze River, in Yunnan Province, southwest China. The water surface area is $48.25 \mathrm{~km}^{2}$ within $246.26 \mathrm{~km}^{2}$ of the catchment area. The average water depth is $40.3 \mathrm{~m}$ with a maximum of $93.5 \mathrm{~m}$, and the water volume is $1.953 \times 10^{9} \mathrm{~m}^{3}$ (Wang \& Dou, 1998). The multi-year mean of the total annual precipitation is about $920 \mathrm{~mm}$, and the mean annual temperature is $12.7{ }^{\circ} \mathrm{C}$ with a minimum of $-10.3{ }^{\circ} \mathrm{C}$ and a maximum of $31.4{ }^{\circ} \mathrm{C}$ (Wang \& Dou, 1998). This lake is supplied mainly by surface runoff from the catchment. As a deep-water lake, the seasonal stratification is significant and the thermocline generally develops at a depth of $14.4 \mathrm{~m}$ (Wang \& Dou, 1998). The lake catchment is an under-populated region, and the forest land, farming land and residential land occupies about $68.9 \%, 11.77 \%$ and $1.56 \%$, respectively of the catchment area (Cai, 2014). Lugu Lake is considered to be an oligotrophic lake with a mean TP concentration of $11.7 \mu \mathrm{g} / \mathrm{L}$ (Chen et al., 2014).

(2) Taibai Lake $\left(29.13^{\circ} \mathrm{E}, 115.8^{\circ} \mathrm{N}, 16 \mathrm{~m}\right.$ a.s.l) is located in the middle reach of the Yangtze River, Hubei Province, eastern China. The water surface area is $25.1 \mathrm{~km}^{2}$ within $960 \mathrm{~km}^{2}$ of the catchment area. The average water depth is $3.2 \mathrm{~m}$ with a maximum of $3.9 \mathrm{~m}$, and the water volume is about $8 \times 10^{7} \mathrm{~m}^{3}$ (Wang \& Dou, 1998). The multi-year mean of the total annual precipitation is about $1,272.5 \mathrm{~mm}$, and the mean annual temperature is $16.7{ }^{\circ} \mathrm{C}$ with a minimum of $-13.8^{\circ} \mathrm{C}$ and the maximum of $39.8^{\circ} \mathrm{C}$ (Wang \& Dou, 1998). Water supply derives primarily from surface runoff (Wang \& Dou, 1998). The lake catchment is a typical agriculture area, and the forest land, farming land and residential land occupies about $16.55 \%, 71.4 \%$ and $4.37 \%$, respectively, of the total area (Liu et al., 2007). According to the investigation in $2002 \mathrm{AD}$, the mean TP concentration is about 125.5 
$\mu \mathrm{g} / \mathrm{L}$ (Dong, Yang, \& Liu, 2006), which is classified as the eutrophication level.

(3) Taihu Lake $\left(30.27^{\circ}\right.$ E, $120.7^{\circ} \mathrm{N}, 3.14 \mathrm{~m}$ a.s.l) is located in the lower reach of the Yangtze River, Jiangsu Province, eastern China. The lake surface covers an area of $2,425 \mathrm{~km}^{2}$ within $36,500 \mathrm{~km}^{2}$ of the catchment area. The average water depth is $2.12 \mathrm{~m}$ with a maximum of $3.3 \mathrm{~m}$, and the water volume is about $5.142 \times 10^{9} \mathrm{~m}^{3}$ (Wang \& Dou, 1998). The multi-year mean of total annual precipitation is about $1,084 \mathrm{~mm}$, and the mean annual temperature is $16{ }^{\circ} \mathrm{C}$ with a minimum of $-16^{\circ} \mathrm{C}$ and a maximum of $39.4{ }^{\circ} \mathrm{C}$ (Wang \& Dou, 1998). Due to the shallow water depth, there is no seasonal stratification in the vertically well mixed water column. The forest land, agricultural land and building land respectively occupies $9.74 \%, 27.42 \%$ and $33.29 \%$ of the North Taihu catchment area (Li, Bi, \& Tian, 2012). The mean TP concentration is $172 \mu \mathrm{g} / \mathrm{L}$ (Qin et al., 2011), which indicates a hypertrophic level of water quality.

(4) Additionally, Pyhäjärvi Lake in SW Finland $\left(61.00^{\circ} \mathrm{N}, 22.18^{\circ} \mathrm{E}, 45 \mathrm{~m}\right.$ a.s.l) was introduced as the reference in the present study. The lake surface is $155 \mathrm{~km}^{2}$ and the catchment area is $616 \mathrm{~km}^{2}$ (Ventelä, Tarvainen, Helminen, \& Sarvala, 2007). The mean and maximum water depths are $5.5 \mathrm{~m}$ and $26 \mathrm{~m}$ respectively, and the water volume is $8.49 \times 10^{7} \mathrm{~m}^{3}$ (Ventelä et al., 2007). The multi-year mean of the total annual precipitation in this region is about $590 \mathrm{~mm}$, and the mean annual temperature is $4.8{ }^{\circ} \mathrm{C} \mathrm{(http://en.ilmatieteenlaitos.fi/).} \mathrm{The} \mathrm{water}$ quality of Pyhäjärvi Lake is now in a mesotrophic level, with a mean TP concentration of $19.5 \mu \mathrm{g} / \mathrm{L}$ (Jeppesen et al., 2012).

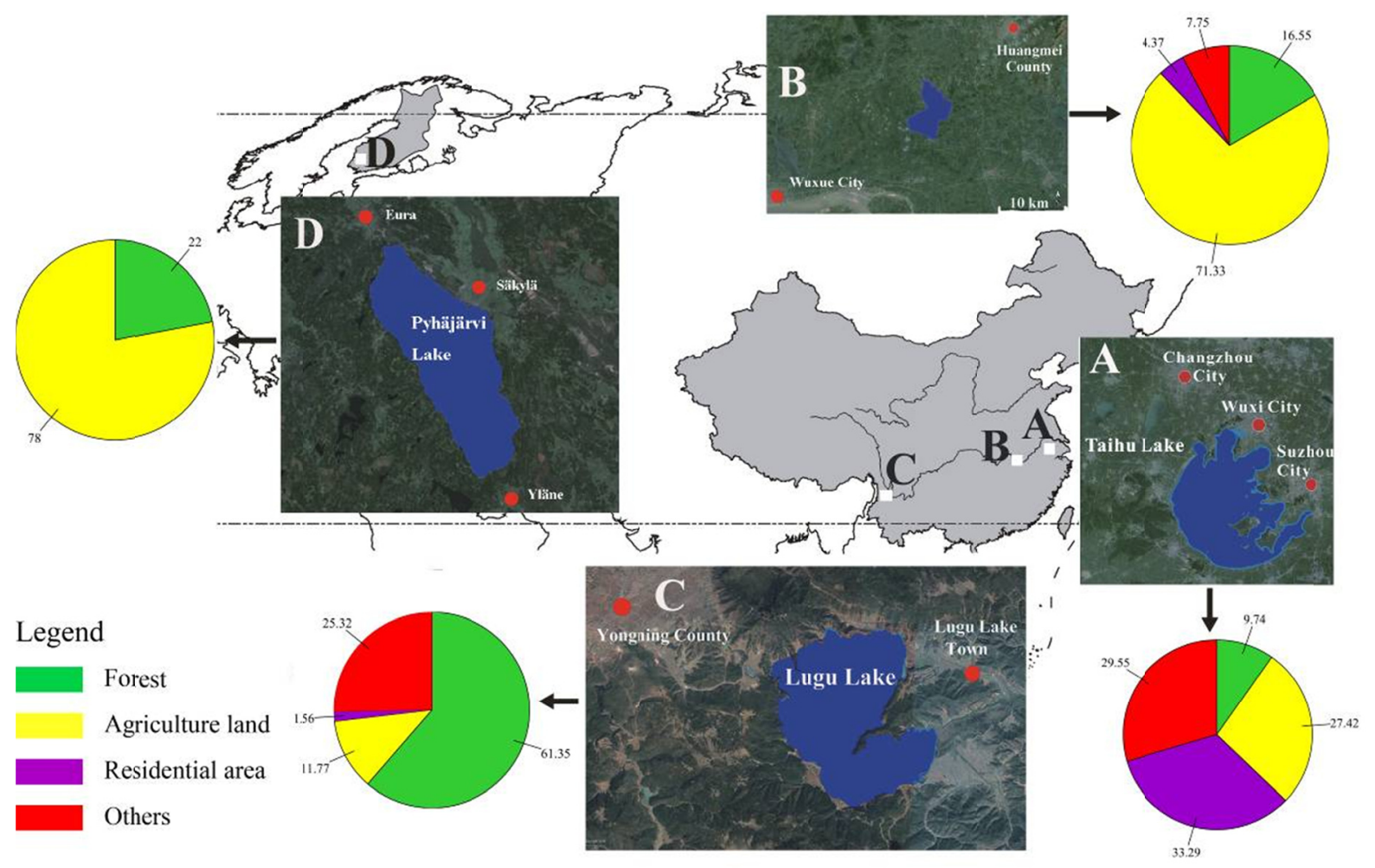

Figure 1. Locations and the land-use types of Lakes Lugu, Taibai, Taihu and Pyhäjärvi

\section{Material}

\subsection{Regional Meteorological Data}

To obtain long-term precipitation and evaporation data of these four lakes, we firstly collected observed data from the meteorological stations nearby. Data from different stations were then combined by using Inverse Distance Weighted (IDM) method. This method uses the inverse square of the distances between the observation stations and the targeted lake as the weights to estimate the meteorological data of the lake. In this study, we used the data from stations at Kunming $\left(25.02^{\circ} \mathrm{N}, 102.68^{\circ} \mathrm{E}\right)$, Xichang $\left(27.90^{\circ} \mathrm{N}, 102.30^{\circ} \mathrm{E}\right)$, Huili $\left(26.65^{\circ} \mathrm{N}\right.$, $\left.102.25^{\circ} \mathrm{E}\right)$, Ya' an $\left(29.98^{\circ} \mathrm{N}, 103.00^{\circ} \mathrm{E}\right)$, Dali $\left(25.72^{\circ} \mathrm{N}, 100.18^{\circ} \mathrm{E}\right)$, and Lijiang $\left(26.87^{\circ} \mathrm{N}, 100.18^{\circ} \mathrm{E}\right)$ to estimate precipitation and temperature for Lugu Lake. Data from Wuhan $\left(31.11^{\circ} \mathrm{N}, 118.38^{\circ} \mathrm{E}\right)$, Jiujiang $\left(29.73^{\circ}\right.$ 
$\left.\mathrm{N}, 116.00^{\circ} \mathrm{E}\right)$, Huangshi $\left(30.30^{\circ} \mathrm{N}, 115.10^{\circ} \mathrm{E}\right)$, and Anqing $\left(30.53^{\circ} \mathrm{N}, 117.05^{\circ} \mathrm{E}\right)$ stations were collected to estimate precipitation and temperature data of Taibai Lake. The precipitation and temperature of Taihu Lake were calculated based on the data from stations at Shanghai $\left(31.40^{\circ} \mathrm{N}, 121.47^{\circ} \mathrm{E}\right)$, Nanjing $\left(32.00^{\circ} \mathrm{N}, 118.80^{\circ}\right.$ E), Zhenjiang $\left(32.20^{\circ} \mathrm{N}, 119.50^{\circ} \mathrm{E}\right)$, Nantong $\left(32.00^{\circ} \mathrm{N}, 120.90^{\circ} \mathrm{E}\right)$, Lishui $\left(28.47^{\circ} \mathrm{N}, 119.92^{\circ} \mathrm{E}\right)$, Wuhu $\left(31.33^{\circ}\right.$ $\left.\mathrm{N}, 118.38^{\circ} \mathrm{E}\right)$. Data from Pyhäjärvi Lake were estimated based on the observations of Turku $\left(60.52^{\circ} \mathrm{N}, 22.27^{\circ}\right.$ E), Tampere airport $\left(61.47^{\circ} \mathrm{N}, 23.73^{\circ} \mathrm{E}\right)$, and Helsinki aero $\left(60.30^{\circ} \mathrm{N}, 25.00^{\circ} \mathrm{E}\right)$ stations. The observations from 1950-2010 AD were derived from the National Climate Center of China (http://ncc.cma.gov.cn/cn/) and the Finnish Meteorological Institute (http://en.ilmatieteenlaitos.fi/). Data before 1950 AD were sourced from Vose et al. (2008). The finally estimated precipitation and temperature series are shown in Figure 2.

(a)

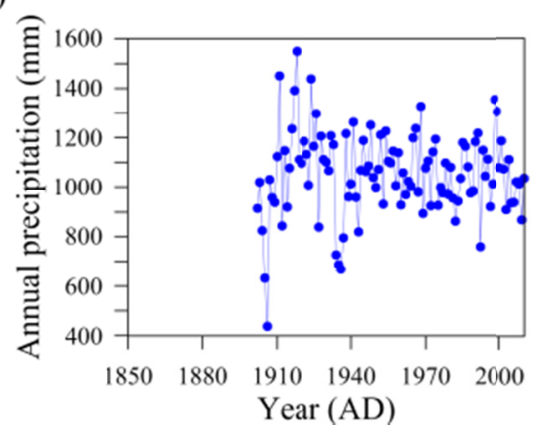

(c)

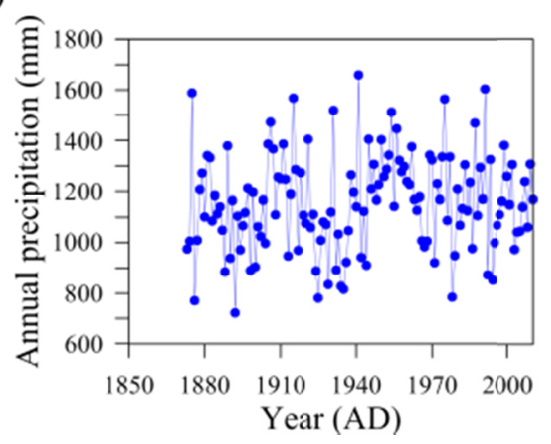

(e)

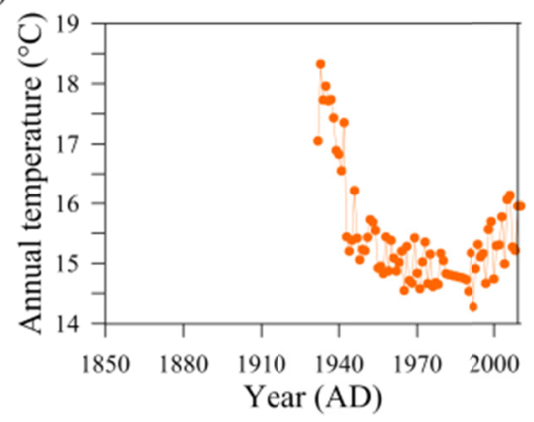

(b)

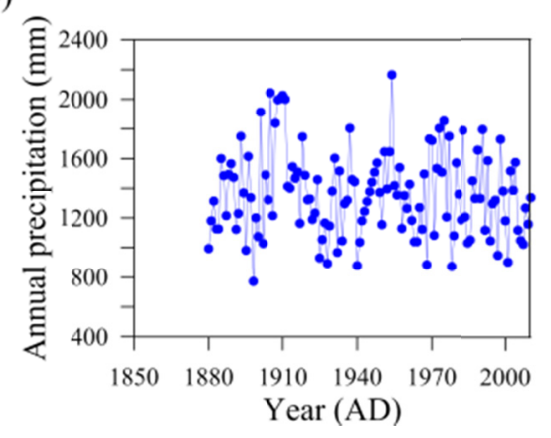

(d)

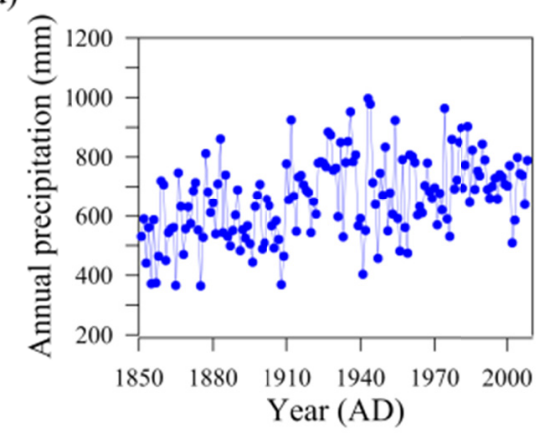

(f)

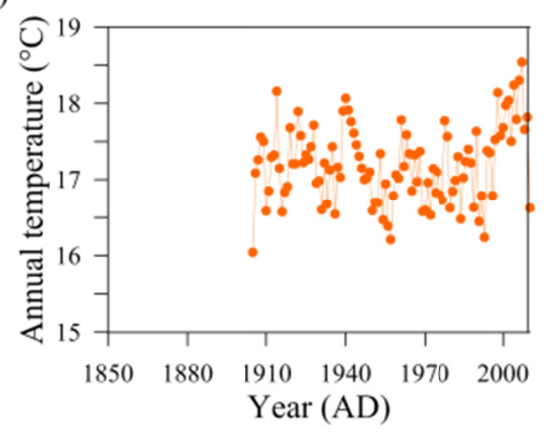


(g)

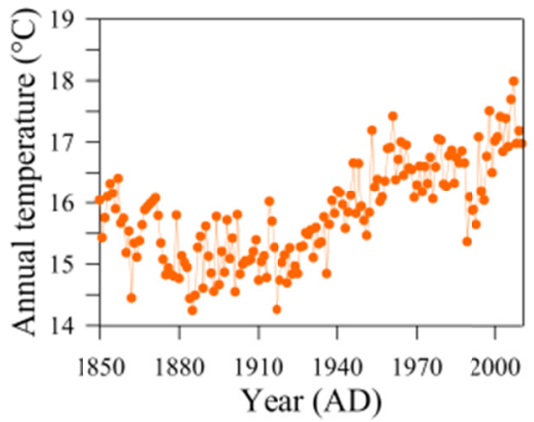

(h)

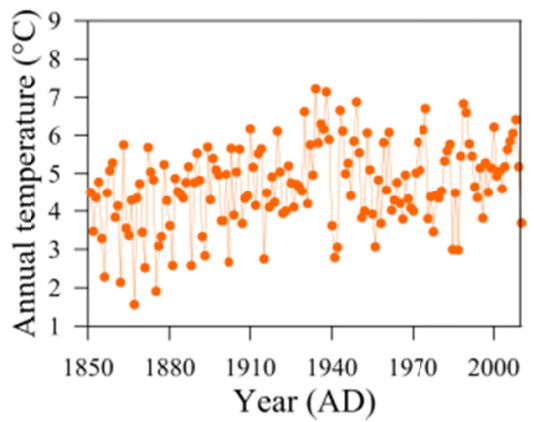

Figure 2. Annual precipitation series for (a) Lugu Lake (1902-2010 AD), (b) Taibai Lake (1880-2010 AD), (c) Taihu Lake (1873-2010 AD) and (d) Pyhäjärvi Lake (1850-2010 AD), and annual temperature series for (e) Lugu Lake (1932-2010 AD), (f) Taibai Lake (1905-2010 AD), (g) Taihu Lake (1850-2010 AD) and (h) Pyhäjärvi Lake (1850-2010 AD)

\subsection{Fossil Diatom and Chronology Data}

Diatom and chronological data for Lakes Lugu, Taibai, Taihu and Pyhäjärvi were sourced from published literature (Chen et al., 2014; Dong et al., 2006, 2008; Weckström et al., 2015). The abundance (\%) of diatom species and chronological data of Lakes Taibai, Taihu and Pyhäjärvi were directly provided by the authors, while those of Lugu Lake were digitized from the paper (Chen et al., 2014). The collected data were used in further analysis. Other information, such as the lengths of the sediment cores, sampled intervals and dates, were all sourced from these published papers:

(1) A 27.5-cm sediment core was retrieved from Lugu Lake and sampled at $0.5-\mathrm{cm}$ intervals. The chronology was established by ${ }^{210} \mathrm{~Pb}$ and ${ }^{137} \mathrm{Cs}$ dating and the bottom sediment was estimated at $1830 \mathrm{AD}$ (Chen et al., 2014). In the total of 145 diatom taxa identified, the dominant species consists mainly of Cyclostephanos dubius, Cyclotella rhomboideo-elliptica, C. ocellata and Pseudostaurosira brevistriata (Chen et al., 2014, Figure 3a).

(2) In Taibai Lake, a $1.5-\mathrm{m}$ sediment core was retrieved. The upper $50-\mathrm{cm}$ section was sampled at $0.5-\mathrm{cm}$ intervals and the rest at $1-\mathrm{cm}$ intervals. The deposition at $42-\mathrm{cm}$ depth was estimated at $1832 \mathrm{AD}$ based on the ${ }^{210} \mathrm{~Pb}$ and ${ }^{137} \mathrm{Cs}$ dating (Dong et al., 2006). Dominant species in the total of 98 diatom taxa are Aulacoseira ambigua, A. granulate, A. alpigena, A. formosa and Gyrosigma acuminatum (Dong et al., 2006, Figure 3b).

(3) There was a $0.5-\mathrm{m}$ sediment core drilled from Meiliang Bay, North Taihu Lake. The samples were obtained at each 0.25 -cm intervals. The age at 6-cm depth was estimated to be $1920 \mathrm{AD}$ according also to the ${ }^{210} \mathrm{~Pb}$ and ${ }^{137} \mathrm{Cs}$ dating (Dong et al., 2008). Dominant species in the total of 78 diatom taxa are mainly composed by A. ambigua, A. granulata, A. alpigena, A. formosa and C. dubius (Dong et al., 2008, Figure 3c).

(4) In Pyhäjärvi Lake, a total of 295 diatom taxa were identified from the sediment samples. The dominant species mainly consists of Fragilaria crotonensis, F. construens $f$. venter, Tabellaria flocculosa, T. flocculosa IV and Stephanodiscus minutulus (Weckström et al., 2015, Figure 3d). 

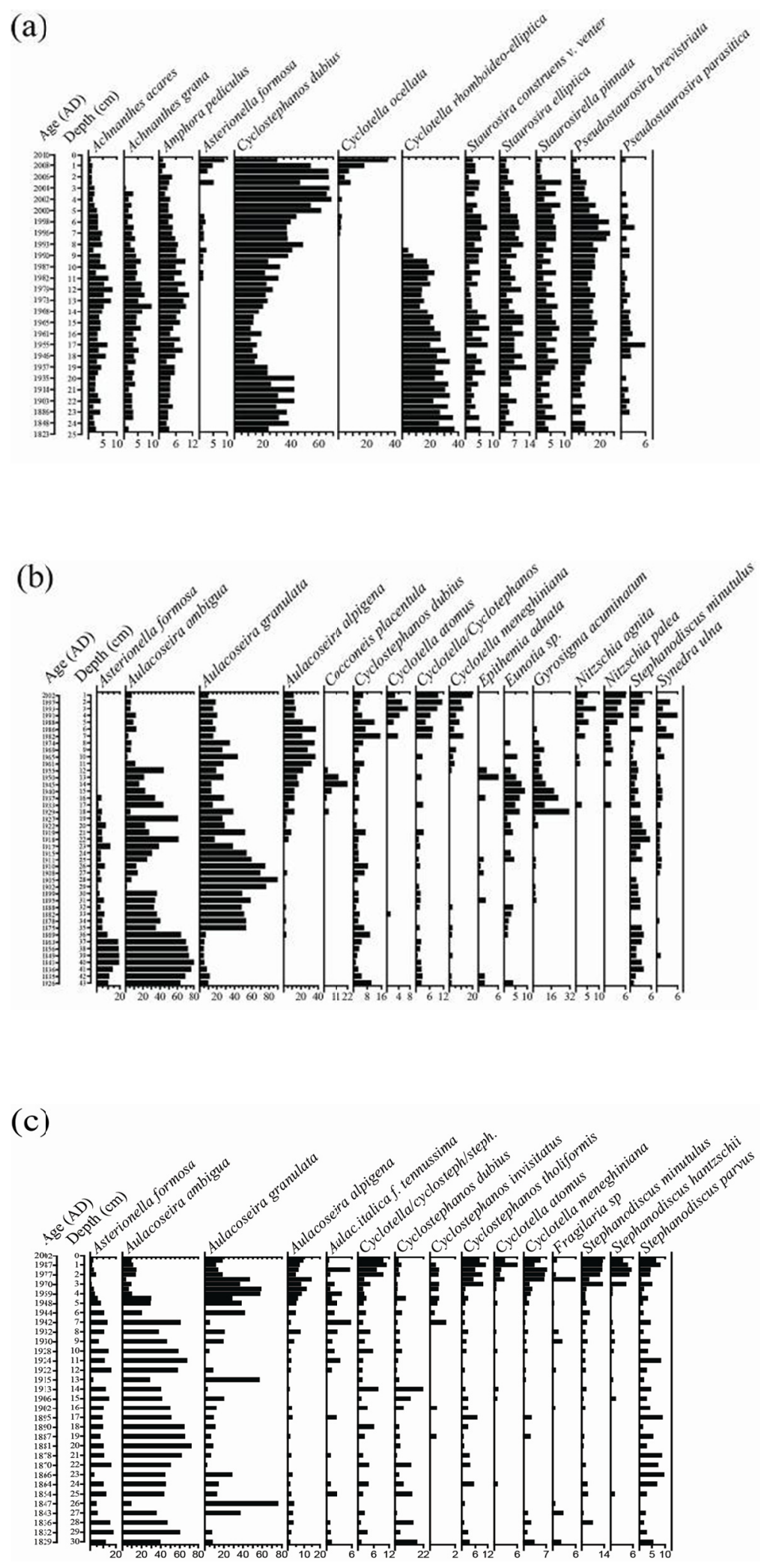


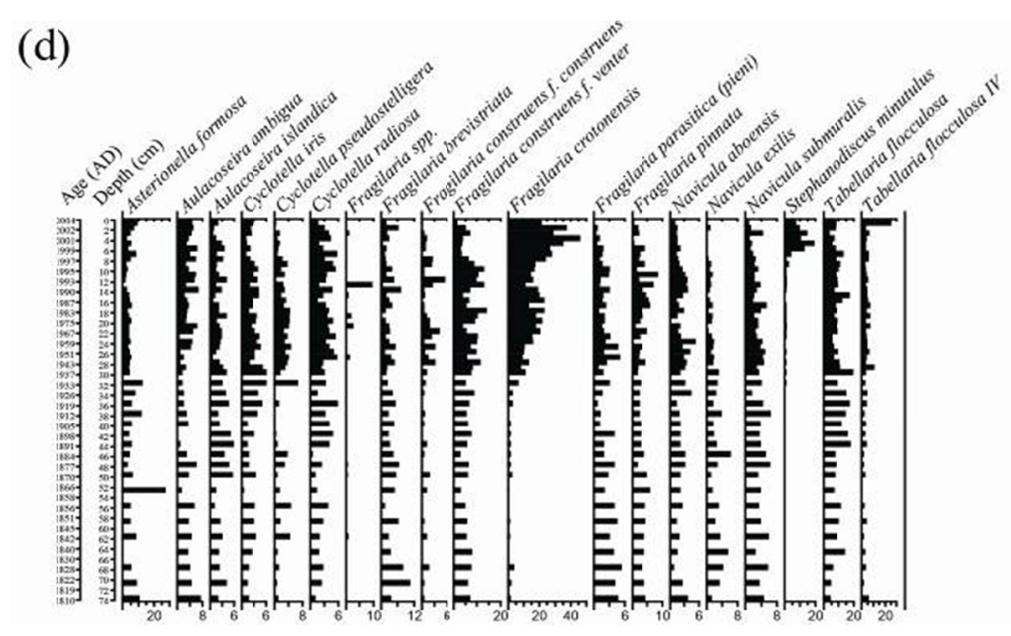

Figure 3. Diatom stratigraphies for taxa with percentages > 5\%: (a) Lugu Lake; (b) Taibai Lake; (c) Taihu Lake; (d) Pyhäjärvi Lake. The four diagrams were redrawn on the basis of data from Chen et al. (2014), Dong et al.

(2006), Dong et al. (2008) and Weckström et al. (2015)

\subsection{Data of Human Activities}

These four lakes and their catchments we focused have been intensively influenced by human activities during the recent decades.

(1) Lugu catchment is a remote and low-economic area. Regional tourism has developed since 1992 AD (Yang, 2013). According to statistical data, tourist numbers increased rapidly from $3.6 \times 10^{4}$ in $1992 \mathrm{AD}$ to $58.6 \times 10^{4}$ in 2012 AD (Yang, 2013). The fast rate of tourism development has driven the main impact on water quality changes in Lugu Lake (Zhang, 2014). The data of tourist number in Lugu region were collected from Yang (2013).

(2) According to Liu et al. (2007), the lake area decreased from $60.1 \mathrm{~km}^{2}$ in the mid-1950s to $27.02 \mathrm{~km}^{2}$ in 1978 $\mathrm{AD}$, and changed little after that. The fast change in the underlying surface condition has played an important part in affecting water quality changes in Taibai Lake. The data of reclamation area were collected from Liu et al. (2007).

(3) North Taihu region is a densely populated and highly urbanized area. According to the Statistic Database of Chinese Economic and Social Development, population in this region increased rapidly from $\sim 580 \times 10^{4}$ in 1949 $\mathrm{AD}$ to $\sim 1,106 \times 10^{4}$ in $1998 \mathrm{AD}$ (http://tongji.cnki.net/kns55/index.aspx). Thus the rapidly increasing population is one of the most important indices for reflecting the regional economic development, and also a major influence on water quality changes in Taihu Lake. The population data used in this studywere sourced from the Statistic Database of Chinese Economic and Social Development (http://tongji.cnki.net/kns55/index.aspx).

(4) The agriculture in Pyhäjärvi catchment has accelerated since the mid-1940s and become very intensive at present due to the increasing use of artificial fertilizers (Valkama, Uusitalo, Ylivainio, Virkajärvi, \& Turtola, 2009; Antikainen, Haapanen, Lemola, Nousiainen, \& Rekolainen, 2008). Therefore, the fertilizer usage is an important index of human activity in this region. The usage of fertilizers in Lake Pyhäjärvi catchment were sourced from http://luonnontila.fi/ext/fi/data-pages/ma3-taustatiedot.html, and it is estimated based on national agricultural statistics (www.tilastokeskus.fi) and earlier publication (Antikainen et al., 2008).

\section{Methods}

In this paper, we used two approaches to reconstruct the nutrient changes in the lakes of Lugu, Taibai, Taihu and Pyhäjärvi. One is using a paleolimnological method based on the diatom-inferred nutrients in the lake sediment records. The other is constructing a lake climate-nutrient dynamic model to simulate nutrient changes, where the nutrients were indicated by total phosphorus (TP).

\subsection{Major Signals of Diatom Assemblages}

Diatoms are ecologically sensitive to water nutrient changes, and are commonly used for lake monitoring and palaeolimnology (Smol, 1992; Hall \& Smol, 2000). The effect of the increased nutrient concentration can be seen as increases in diatoms favoring elevated nutrient levels in Lakes Lugu (Chen et al., 2014), Taibai (Dong et 
al., 2006), Taihu (Dong et al., 2008), and Pyhäjärvi (Weckström et al., 2015). We therefore used the diatom assemblage variations in lake sediments to reflect nutrient changes during historical periods. In this paper, the method of Principle Component Analysis (PCA) was applied to extract the principal component (PC) of diatom assemblages. PCA is an approach aimed at extracting a few PCs to replace numerous original variables by using the dimension reduction method, and should reflect original information as much as possible. Therefore, the PC can capture the major signals of diatom assemblage variations, which was used as a lake nutrient proxy in this study.

The PCA was performed in C2 program Version 1.5 (Juggins, 2003), when only diatoms with abundances $>2 \%$ were included in the dataset. Before running the PCA, we constructed a data matrix. The columns of the matrix were the abundances (\%) of different diatom species, and the rows corresponded to the top-down samples from the lake sediment cores. In the dataset, the sample numbers of Lakes Lugu, Taibai, Taihu and Pyhäjärvi were 16, 24, 28 and 103 respectively, and the species numbers were 50, 46, 35 and 48 respectively.

\subsection{Lake Climate-Nutrient Dynamic Model}

Although diatom assemblages and the extracted signals from lake sediments can reflect the combined effect of climatic and anthropogenic impacts on water quality changes, and also can infer the potential main-control forces, it can hardly distinguish climatic influence from anthropogenic impacts. Nutrients are important for water quality changes (Kalff, 2002), among which total phosphorus (TP) is one of the most important component to evaluate lake nutrient levels (Vollenweider, 1968). This is also the case with most Chinese lakes (Wang \& Dou, 1998). Therefore, a lake climate-nutrient dynamic model was constructed to simulate TP changes controlled by natural conditions such as precipitation, evaporation, runoff, regional hydrology and the geomorphology, and so on.

Lake nutrient accumulation and discharge are significantly affected by lake morphology and hydrology, and the nutrient equilibrium is greatly influenced by water exchange speed (Vollenweider, 1968). Based on the analysis for the morphological characteristics and hydrological data from 30 lakes in Europe and North America, Vollenweider (1968) proposed a relationship of lake nutrient concentration $\left(C_{l}\right)$, catchment nutrient concentration $\left(C_{r}\right)$ and hydraulic residence time $(\tau)$. Larsen and Mercier (1976) then improved Vollenweider's mode and proposed the relationship described as:

$$
C_{l}=C_{r} /\left(1+\tau^{-1 / 2}\right)
$$

Hydraulic residence time is defined as the time length lake water needs to change once, and it can be expressed as:

$$
\tau \equiv V / Q
$$

Where $V$ is the lake volume, $Q$ is the net inflow. By introducing the concept of hydrologic budget $(P+R-E-Q=0)$, Equation (2) can be expressed as:

$$
\tau=V /(P+R-E)
$$

Wherein $P, R, E$ represent lake surface precipitation, catchment-derived runoff and lake surface evaporation.

Water phosphorus load $\left(P_{l}\right)$ is the function of discharge $(Q)$ and concentration $\left(C_{l}\right): P_{l}=C_{l} Q P_{l}$ can be calculated according to the formula below:

$$
P_{l}=C_{r} Q /\left(1+\tau^{-1 / 2}\right)
$$

In this paper, Equation (4) was used to calculate TP content with lake morphology and hydrology as boundary conditions, and was applied to estimate changes of lake water quality. For comparison purpose, the TP load was divided by the lake volume to convert to TP concentration. Model validation has been done by a control test published in Yu, Liao, and Li (2013) and Guo, Yu, and Qin (2015).

\subsection{Total Variance Explained}

To further explain the variations of climatic and anthropogenic impacts on the water quality change, we introduced an index of relative variance in this study. For comparison purpose, time series of the PCs, temperature and human activity index were normalized and calculated the standard deviations. Finally, we used a ratio of standard deviation of temperature (or human activity index) to that of PCs, in order to describe the contribution weighting of temperature (or human activity). In this paper, the ratio can reflect the fitting degree between two compared series. Namely, the higher ratio indicates better fitting, while lower ratio indicates poor fitting. 


\section{Results}

\subsection{PCA Results of Diatom Assemblages}

The diatom assemblages in all four lakes show marked changes during the past 150 years. According to the PCA results, the first PCs (PC1s) explain $69.06 \%, 61.02 \%, 72.53 \%$ and $85.5 \%$ of the diatom assemblage variations in Lakes Lugu, Taibai, Taihu and Pyhäjärvi, respectively.

The four lakes show the features of each change. The PC1 in Lugu Lake was relative stable and fluctuated within a certain range before ca. $1950 \mathrm{AD}$, following a slight increase during ca. 1950-1990 AD; after that, it increased rapidly with persistent fluctuations. The PC1 in Taibai Lake fluctuated dramatically but maintained a low value before ca. $1950 \mathrm{AD}$, after that, it increased rapidly during ca. 1950-1980 AD and then changed a little. The PC1 in North Taihu Lake increased gradually during the period of ca. 1870-1910 AD, following a sharp increase, and then it decreased markedly to a trough in ca. 1925 AD. After that, it increased with fluctuations until ca. 1970 AD and then declined suddenly. After ca. 1990 AD, it showed an increasing trend again. The PC1 in Pyhäjärvi Lake increased slowly since ca. 1910 AD, following a slight decline during ca. 1980-1990 AD, and then it increased rapidly until $2000 \mathrm{AD}$ and decreased rapidly after that (Figures 4a-4d).

(a)

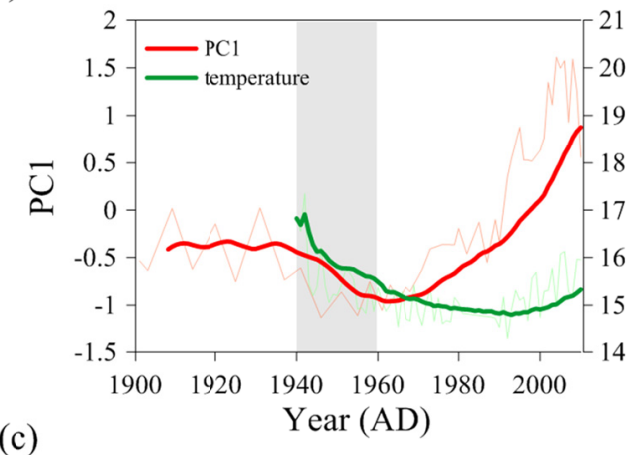

(c)

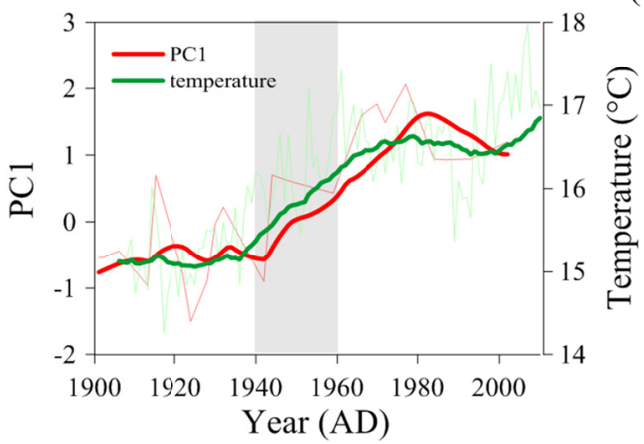

(b)

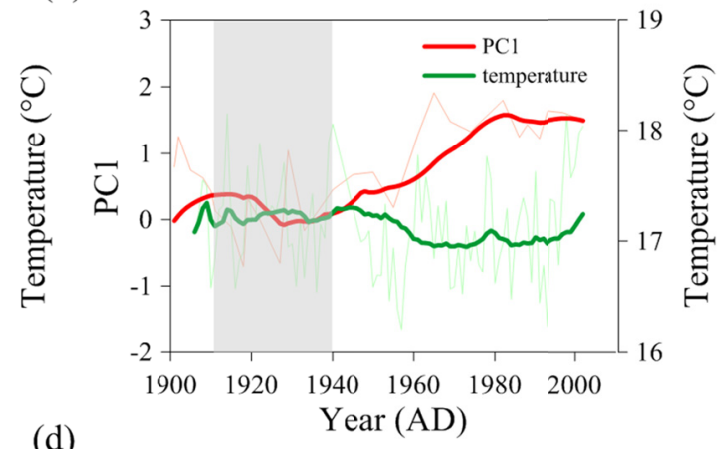

(d)

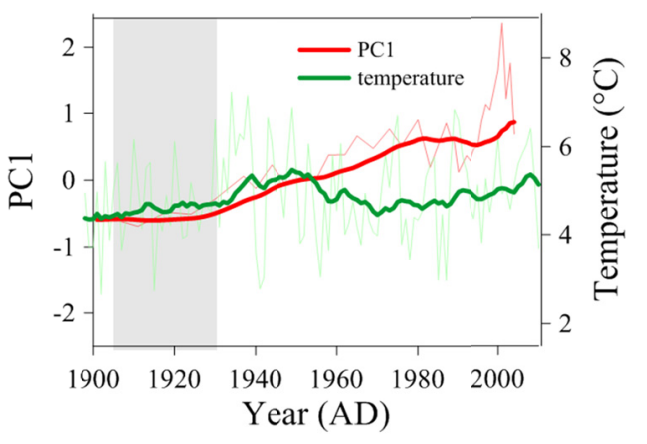

Figure 4. Comparisons of PC1s with regional temperature in (a) Lugu Lake, (b) Taibai Lake, (c) Taihu Lake, and (d) Pyhäjärvi Lake

\subsection{Fitting Results of PCs with Climate and Human Activity Records}

To further determine which variable majorly affected the changes of water quality, PCs were correlated with climate data and human activity records. The correlation analysis results show that the PCs in these four lakes have bad correlations with precipitation, while they are partially relevant to regional temperature. Based on the correlation results, we found that the PC1 series of the diatom variations in Lugu Lake changed consistently with temperature before ca. $1960 \mathrm{AD}$, but they separated afterwards (Figure 4a). The PC1 series of the diatom variations in Taibai Lake changed similarly with temperature during ca. 1900-1940 AD, after that, they changed inversely (Figure 4b). The PC1 and temperature changes in Taihu Lake displayed a similar trend throughout the whole period (Figure 4c). We have also checked that the PC1 in Pyhäjärvi Lake changed consistently with temperature variations during 1900-1930 AD; after that, they changed in reversed trajectories (Figure 4d). Based on the comparisons, we found that the best fittings in Lakes Lugu, Taibai, Taihu and Pyhäjärvi appeared in the periods of ca. 1940-1960 AD, ca. 1910-1940 AD, ca. 1940-1960 AD, and ca. 1900-1930 AD, respectively. 
The calculation results of relative variance, for the best fitting periods, show that water quality changes in Lakes Lugu, Taibai, Taihu and Pyhäjärvi captured $68.4 \%, 54.9 \%, 86.0 \%$ and $56.6 \%$ of the temperature variations, respectively.

As PC1s in recent decades fits badly with temperature, we tried to use human activity indices in different regions to do the fittings, and then calculated the relative variance for each series. According to the fitting results, the PC1 in Lugu Lake was fitted well with the rapidly increasing of tourist numbers during 1992-2012 AD (Figure 5a). The PC1 in Taibai Lake changed consistently with lake reclamation area during the mid-1950s to 2002 AD (Figure 5b). The PC2 in Taihu Lake shows a similar trend with the fast-increasing population (Figure 5c). In Pyhäjärvi Lake, the PC1 shows a similar trend with the changes in fertilizer usage, though it lagged a few years behind (Figure 5d). The calculation results of relative variances show that the human activities explained $84.0 \%$, 96.4\%, 96.0\% and 73.6\% of the PCs changes in Lakes Lugu, Taibai, Taihu and Pyhäjärvi, respectively.

(a)

(c)
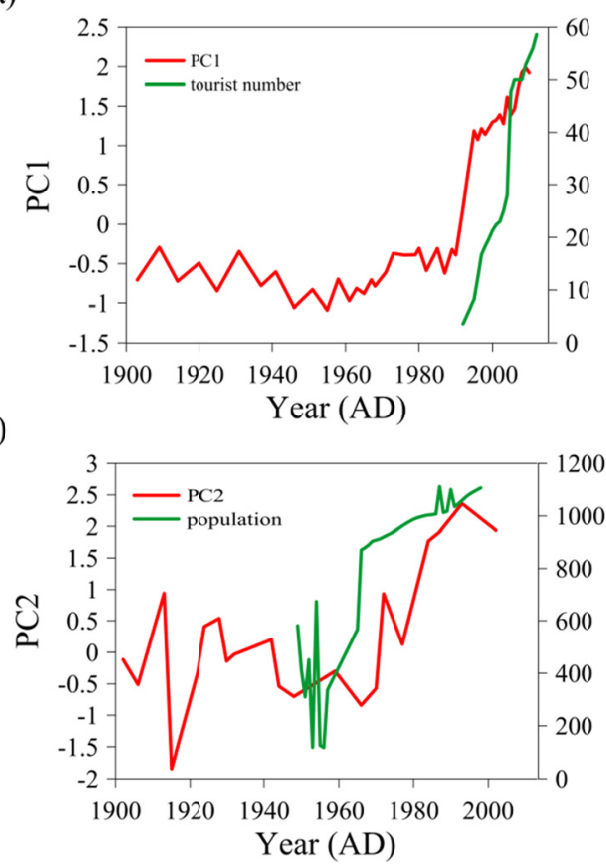

(b)
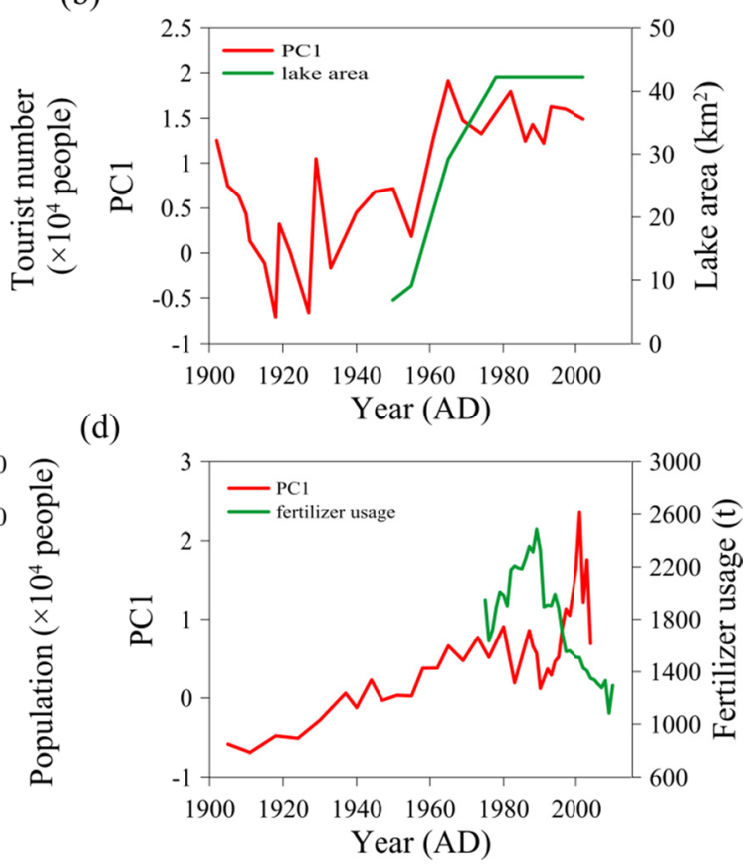

Figure 5. Comparisons of PCs with human activity indexes in (a) Lugu Lake, (b) Taibai Lake, (c) Taihu Lake, and (d) Pyhäjärvi Lake

\subsection{Simulation Results}

The lake nutrient modeling for the four lakes (Figure 6) show the individual changes:

(1) The simulated TP in Lugu Lake has increased since 1910 AD to a peak in 1925 AD, and then declined to a trough in $1940 \mathrm{AD}$. After that, it increased gradually to the mean level in $1950 \mathrm{AD}$, and fluctuated within a certain extent afterwards;

(2) The simulated TP changes in Taibai Lake show high oscillations during 1880-1970 AD, with two distinctive peaks in $1950 \mathrm{AD}$ and $1975 \mathrm{AD}$, and two troughs in $1930 \mathrm{AD}$ and $1970 \mathrm{AD}$. After that, it decreased within slight fluctuations;

(3) The simulated TP in Taihu Lake was relative stable during 1850-1890 AD, following intense fluctuations until $1960 \mathrm{AD}$, with peaks in $1900 \mathrm{AD}$ and $1930 \mathrm{AD}$, and troughs in $1920 \mathrm{AD}$ and $1960 \mathrm{AD}$. After that, it increased gradually until $1975 \mathrm{AD}$, and finally maintained a relative stable level;

(4) The simulated TP in Pyhäjärvi Lake increased slightly during 1850-1890 AD, and then decreased. It increased rapidly since $1910 \mathrm{AD}$, following a slight decline after $1930 \mathrm{AD}$. Then it increased again after 1975 $\mathrm{AD}$ and decreased gradually after $1990 \mathrm{AD}$.

Through comparing the simulation results of the three Chinese lakes, we found that the mean simulated TP of 
Lugu Lake is lowest $(28.6 \mu \mathrm{g} / \mathrm{L})$ while that of Taihu Lake is highest $(90.6 \mu \mathrm{g} / \mathrm{L})$. Taibai Lake is at an intermediate level with a mean simulated TP of $83.8 \mu \mathrm{g} / \mathrm{L}$.

\subsection{Comparing between Simulated TPs and PC1s}

Simulated TP represents lake nutrient changes controlled mainly by climate, while PC1 changes are the result of combined effects of climate and human activities. By comparing the results of the two approaches, we can distinguish the major driving forces on lake water quality changes. The results showed significant turning points between PC1s and simulated TPs in the four lake series (Figure 6).

The turning points of Lakes Lugu, Taibai, Taihu and Pyhäjärvi occurred in the 1990s, 1950s, 1940s and 1930s, respectively. Before the turning points, the PC1s changed similarly with simulated TPs, but they separated with each other after that (Figure 6).

(a)

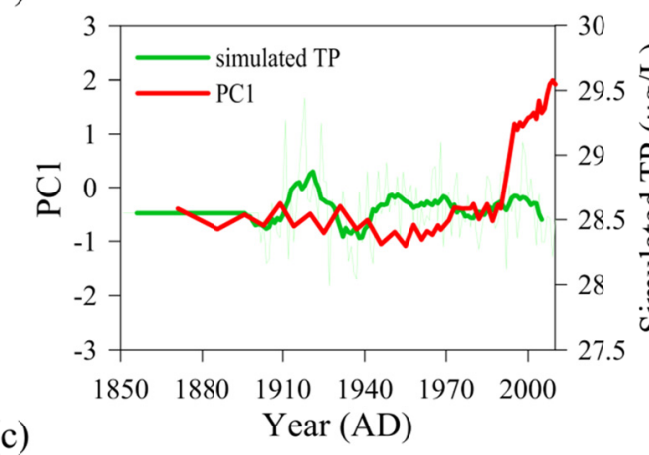

(c)

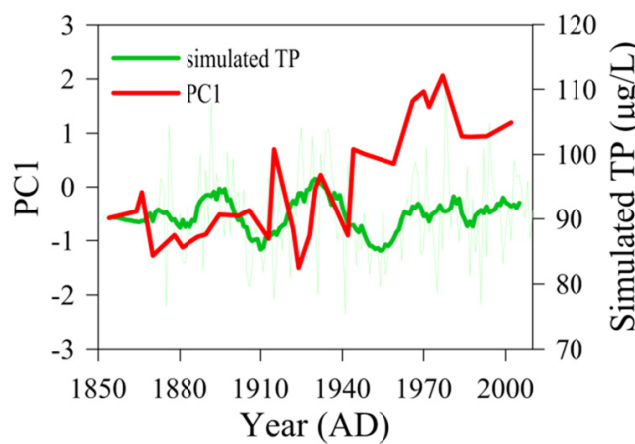

(b)
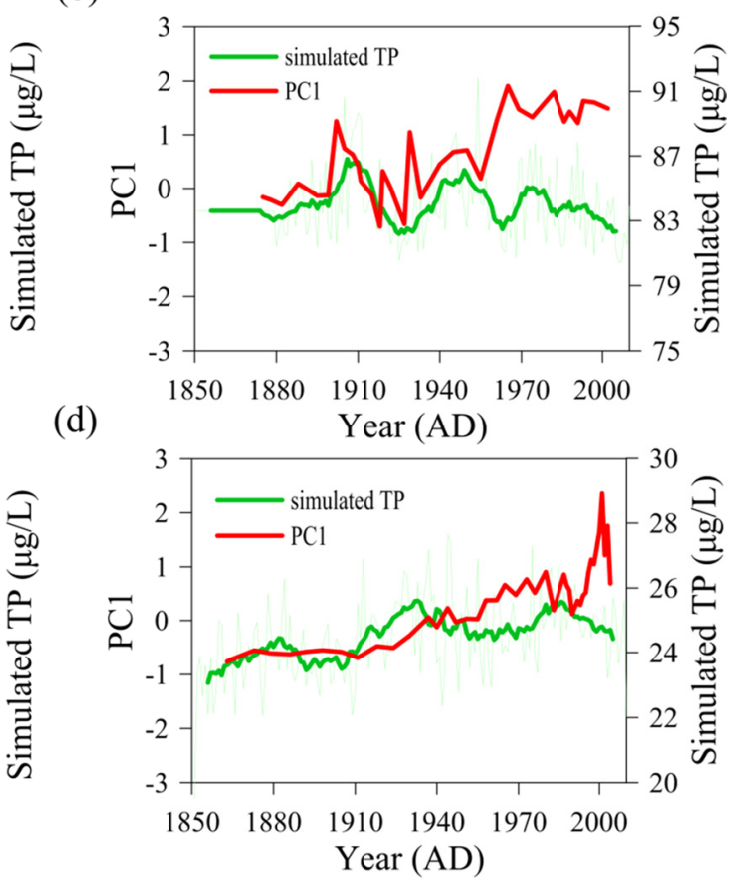

Figure 6. Comparisons of PC1s with simulated TPs for (a) Lugu Lake, (b) Taibai Lake, (c) North Taihu Lake, and (d) Pyhäjärvi Lake

\section{Discussion}

\subsection{The Turning Points and Major Forces of Lake Water Quality Changes}

The PC reflects lake water quality changes affected by both climate and human activities, while the simulated TP reflects the changes controlled primarily by climate. Therefore, different changes between these two series, during the periods before and after the turning points, probably indicate different driving forces. According to the comparisons between series of the PC1s and the simulated TPs, the respective turning points of Lakes Lugu, Taibai, Taihu and Pyhäjärvi occurred in the 1990s, 1950s, 1940s and 1930s respectively (Figure 6). The consistent trends during the periods of pre-turning points probably indicate that lake water quality changes were mainly influenced by natural processes and climate. While the nutrient changes during the periods after the turning points probably indicate that there have other factors influence the changes in lake water quality. From the further comparisons between PC1 (or PC2) and human activity indexes, we found the following points.

(1) Tourism in Lugu region began to develop since $1992 \mathrm{AD}$, which led to a fast-increasing tourist population from $3.6 \times 10^{4}$ in $1992 \mathrm{AD}$ to $58.6 \times 10^{4}$ in $2012 \mathrm{AD}$ (Yang, 2013). This is consistent with the rapidly increasing trend of PC1 since $1990 \mathrm{AD}$. Thus, it can be inferred that tourism development is a major force for water quality changes in Lugu Lake since the early 1990s. 
(2) Agricultural reclamation had been intensive surrounding Taibai Lake during the mid-1950s to late 1970s. The statistical data shows that lake area retained only $41.87 \%$ of the original area in $2002 \mathrm{AD}$ (Liu et al., 2007). The timing of turning point occurrence corresponds to the beginning of extensive lake reclamation, and the changes of $\mathrm{PC} 1$ were consistent with that of reclamation area since the mid-1950s. This probably suggests that agricultural reclamation made a critical impact on water quality changes in Taibai Lake.

(3) Population in Northern Taihu region had increased significantly from $\sim 580 \times 10^{4}$ in 1949 AD to $\sim 1,106 \times 10^{4}$ in $1998 \mathrm{AD}$ according to the Statistic Database of Chinese Economic and Social Development (http://tongji.cnki.net/kns55/index.aspx). Although the PC2 changes lagged $~ 10$ years behind the fast-increasing population, it infers, from the similar increasing trends, that the population pressure has a strong impact on the water quality changes in Taihu Lake.

(4) During the $20^{\text {th }}$ century, the water quality in Pyhäjärvi Lake experienced the process from oligotrophic condition to eutrophication. The significant climate changes over the recent decades have been suggested as an important force for water quality changes in Pyhäjärvi Lake (Ventelä et al., 2011). However, the significant water deterioration during the 1990s, especially the peak of PC1 series in $2000 \mathrm{AD}$, can be hardly explained by the gradual increase of climatic variations such as temperature and precipitation. Therefore, we suggest that human activity has played an important role on water quality changes in Pyhäjärvi Lake during recent decades. Chemical fertilizer was introduced into this region since the mid-1940s, which resulted in the increasing amount of phosphorus and nitrogen nutrient inputting into Pyhäjärvi Lake (Ekholm, Malve, \& Kirkkala, 1997). According to the statistic data, the chemical fertilizer usage in Pyhäjärvi region increased about $51 \%$ from the mid-1970s to the early 1990s, corresponding to an accelerated water deterioration. Intensive water quality restoration measure for Pyhäjärvi Lake has been conducted since 1995 AD. For example, the fertilizer usage in the catchment had decreased from $1888 \mathrm{t} / \mathrm{a}$ in 1995 AD to $1295 \mathrm{t} / \mathrm{a}$ in 2010 AD. The PC1 deceased rapidly since $2000 \mathrm{AD}$, although it lagged a few years behind the decrease in chemical fertilizer usage, is probably a result of these restoration measures.

(a)

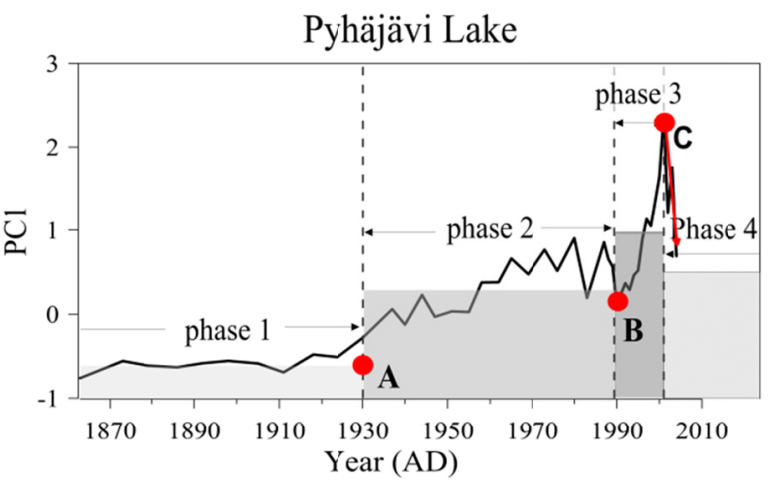

(b)

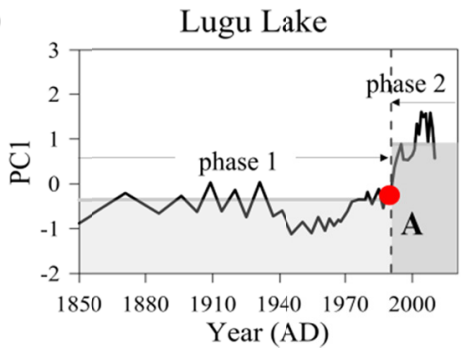

(c)

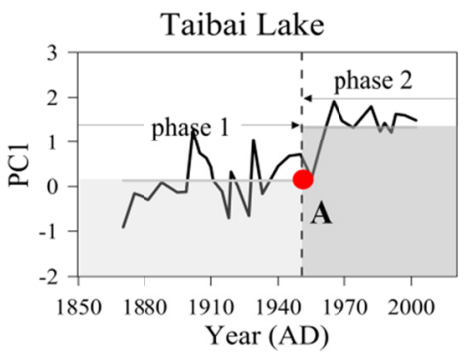

(d)

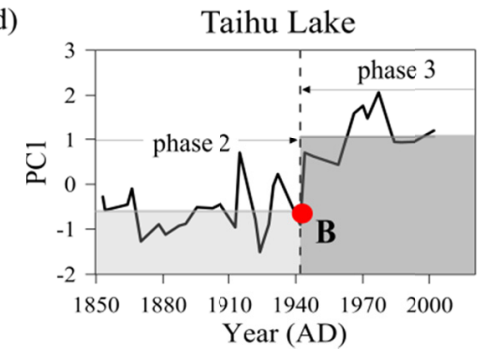

Figure 7. Turning points and change phases in (a) Pyhäjärvi Lake, (b) Lugu Lake, (c) Taibai Lake and (d) Taihu Lake, during the last 150 years. (A, B, and C represent turning points from phase 1 to phase 2 , phase 2 to phase 3 , and phase 3 to phase 4 , respectively)

\subsection{Patterns of Lake Water Quality Responding to Climate and Human Activities}

A lake is an open ecosystem with a self-regulation capacity. Different lakes have different regulation capacities, and thus respond differently to external forces (Kalff, 2002). To reveal lake water quality responding to the changes of temperature and human activities, PCs inferred from diatom assemblages and the temperature and/or 
human activity indexes were used to calculate relative variance. The calculation results show that changes of PC1s in Lakes Lugu, Taibai, Taihu and Pyhäjärvi captured 68.4\%, 54.9\%, 86.0\% and 56.6\% of the temperature variations respectively, during the pre-turning point periods of each lake. These indicate that temperature was the main force controlling lake water quality changes during these periods. The results also show that the human activity indices explained $84.0 \%, 96.4 \%, 96.0 \%$ and $73.6 \%$ of the PC1s (or PC2) change in Lakes Lugu, Taibai, Taihu and Pyhäjärvi, respectively, during the post-turning point periods. These suggest that human activity strongly influenced lake water quality changes during the recent decades.

\subsection{Trends of Lake Water Quality}

According to the PC1 series during the last 150 years, water quality changes in Pyhäjärvi Lake are shown by a four-phase model (Figure 7a): phase 1 is in a stage of oligothrophic condition before the 1930s, phase 2 is in a stage of water quality deterioration during the 1930s-1990s, phase 3 represents a stage of accelerated deterioration during the 1990s-2000s, and phase 4 is in a stage of water recovering since the 2000s. Comparing with Pyhäjärvi Lake, the three Chinese lakes can be inferred to show similar stages. Water quality in Lakes Lugu and Taibai has experienced the processes from phases 1 to 2 during the last 150 years (Figures $7 \mathrm{~b}$ and $7 \mathrm{c}$ ), and Taihu Lake has experienced the process from phases 2 to 3 (Figure 7d). Phase 4, however, has not yet occurred in the Chinese lakes. Based on Pyhäjärvi experiences and our trend analysis, we estimated that water quality of Taihu Lake, now in phase 3, will likely step into phase 4 when the lake is protected and restored by appropriate measures likely in the Pyhäjärvi Lake. The water quality of Lakes Lugu and Taibai, in phase 2 now, will step into phase 3 if they are persistently affected by intensive human activities like the 1990s' situation in the Pyhäjärvi, but it will probably step directly into phase 4 if they are treated by effective protecting measures and management.

\section{Conclusions}

In this study, through combined paleolimnological and simulated approaches, we attempted to diagnose the lake trophic processes and turning points and to estimate the trends of water quality on the reference of Pyhäjärvi Lake. The comparisons between the simulated TPs and the PCs as inferred from the diatom assemlages from lake sediments showed that during the last 150 years, there were significant turning points in water quality changes occurring in the three lakes of China. It occurred in the 1990s in Lugu Lake, resulting primarily from catchment tourism development. The turning point of Taibai Lake occurred in the 1950s, causing by agricultural reclamation. The turning point of Taihu Lake occurred in the 1940s, mainly due to the urbanization in the lake basin. When during the last 150 years, the turning point in Pyhäjärvi Lake occurred in the 1930s, a major result also from increasing influence of human activity in the catchment. According to the calculation results of relative variance, before the turning points of each lake, temperature played a leading role in water quality changes, while during the periods of the post-turning points, human activity was a major force to control water quality change in the eutrophication process.

The change process of water quality in Pyhäjärvi Lake during the last 150 years show four-phase developments (phase 1-4). Comparing with Pyhäjärvi Lake, each of the three Chinese lakes also shows some similarities in the change process of water quality. Water quality in Lakes Lugu and Taibai has experienced the processes from phases 1 to 2 during the last 150 years, and Taihu Lake has experienced the process from phases 2 to 3 , while phase 4 has not occurred in the three Chinese lakes yet. Based on Pyhäjärvi experiences and our trend analysis, we also predicted that the water quality of Taihu Lake will likely step into phase 4 if protection and restoration measures for water quality are taken into practice. Water qualities in Lakes Lugu and Taibai will step into phase 3 if they are persistently affected by intensive human activities, but it will likely step directly into phase 4 if they are protected by effective measures and managements.

\section{Acknowledgements}

Financial support for this work was provided by Global Change Research Program of the China Ministry of Science and Technology (2012CB956103, 2013CB956501), International Cooperation Program of the Chinese Academy of Sciences (KZZD-EW-TZ-08 and GJHZ1214). Anne-Mari Ventelä was supported by the Pyhäjärvi Restoration Program and the Academy of Finland funded projects CARE (203591) and Lakes in Trouble (256240).

\section{Reference}

Antikainen, R., Haapanen, R., Lemola, R., Nousiainen, J. I., \& Rekolainen, S. (2008). Nitrogen and phosphorus flows in the Finnish agricultural and forest sectors, 1910-2000. Water, Air, and Soil Pollution, 194(1-4), 163-177. http://dx.doi.org/10.1007/s11270-008-9705-0 
Anderson, N. J. (1993). Natural versus anthropogenic charge in lakes: The role of the sediment record. Trends in Ecology \& Evolution, 8(10), 356-361. http://dx.doi.org/10.1016/0169-5347(93)90219-F

Cai, W. (2014). Analysis and assessment of the natural and landuse's pattern and water and soil loss of a watershed-A case study in Lugu Lake watershed. (Master's Thesis, East China Normal University, Shanghai, China). Retrieved from http://www.cnki.net/

Carpenter, S. R., Christensen, D. L., Cole, J. J., Cottingham, K. L., He, X., Hodgson, J. R., ... Pace, M. L. (1995). Biological control of eutrophication in lakes. Environmental Science \& Technology, 29(3), 784-786. http://dx.doi.org/10.1021/es00003a028

Chen, C., Zhao, L., Zhu, C., Wang, J., Jiang, J., \& Yang, S. (2014). Response of diatom community in Lugu Lake (Yunnan-Guizhou Plateau, China) to climate change over the past century. Journal of Paleolimnology, 51(3), 357-373. http://dx.doi.org/10.1007/s10933-013-9760-4

Chen, X., Yang, X., Dong, X., \& Liu, Q. (2011). Nutrient dynamics linked to hydrological condition and anthropogenic nutrient loading in Chaohu Lake (Southeast China). Hydrobiologia, 661(1), 223-234. http://dx.doi.org/10.1007/s10750-010-0526-y

Degobbis, D., Precali, R., Ivancic, I., Smodlaka, N., Fuks, D., \& Kveder, S. (2000). Long-term changes in the northern Adriatic ecosystem related to anthropogenic eutrophication. International Journal of Environment and Pollution, 13(1-6), 495-533. http://dx.doi.org/10.1504/IJEP.2000.002332

Dong, X., Bennion, H., Battarbee, R., Yang, X., Yang, H., \& Liu, E. (2008). Tracking eutrophication in Taihu Lake using the diatom record: potential and problems. Journal of Paleolimnology, 40(1), 413-429. http://dx.doi.org/10.1007/s10933-007-9170-6

Dong, X., Yang, X., \& Liu, E. (2006). Diatom records and reconstruction of epilimnetic phosphorus concentration in Lake Taibai (Huibei Province) over the past 400 year. Journal of Lake Sciences, 18(6), 597-604. http://dx.chinadoi.cn/10.3321/j.issn:1003-5427.2006.06.007

Ekholm, P., Malve, O., \& Kirkkala, T. (1997). Internal and external loading as regulators of nutrient concentrations in the agriculturally loaded Lake Pyhäjärvi (southwest Finland). Hydrobiologia, 345(1), 3-14. http://dx.doi.org/10.1023/A:1002958727707

Fritz, S. C. (1989). Lake development and limnological response to prehistoric and historic land-use in Diss, Norfolk, UK. The Journal of Ecology, 182-202. http://dx.doi.org/10.2307/2260924

Guo, Y., Yu, G., \& Qin, B. (2015). Historical trophic evolution resulting from changes in climate and ecosystem in Lake Taihu and seven other lakes, China. Journal of Freshwater Ecology, 30(1), 25-40. http://dx.doi.org/10.1080/02705060.2014.1003618

Hall, R., Leavitt, P., Smol, J., \& Zirnhelt, N. (1997). Comparison of diatoms, fossil pigments and historical records as measures of lake eutrophication. Freshwater Biology, 38(2), 401-417. http://dx.doi.org/10.1046/j.1365-2427.1997.00251.x

Hall, R. I., \& Smol, J. P. (2000). Diatoms as indicators of lake eutrophication. In J. P. Smol, \& E. F. Stoermer (Eds.), The diatoms: Applications for the environmental and earth sciences (pp. 128-168). Cambridge, UK: Cambridge University Press.

Harris, G. P., \& Vollenweider, R. A. (1982). Paleolimnological evidence of early eutrophication in Lake Erie. Canadian Journal of Fisheries and Aquatic Sciences, 39(4), 618-626. http://dx.doi.org/10.1139/f82-087

Howarth, R., Anderson, D., Cloern, J., Elfring, C., Hopkinson, C., Lapointe, B., ... Sharpley, A. (2000). Nutrient pollution of coastal rivers, bays, and seas. Issues in Ecology, 7(7), 1-14.

Jeppesen, E., Meerhoff, M., Jacobsen, B. A., Hansen, R. S., Søndergaard, M., Jensen, J. P., ... Branco, C. W. C. (2007). Restoration of shallow lakes by nutrient control and biomanipulation-The successful strategy

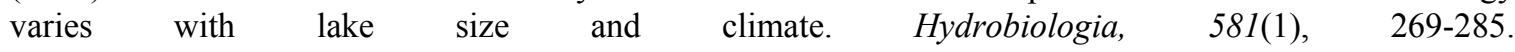
http://dx.doi.org/10.1007/s10750-006-0507-3

Jeppesen, E., Mehner, T., Winfield, I. J., Kangur, K., Sarvala, J., Gerdeaux, D., ... Volta, P. (2012). Impacts of climate warming on the long-term dynamics of key fish species in 24 European lakes. Hydrobiologia, 694(1), 1-39. http://dx.doi.org/10.1007/s10750-012-1182-1

Juggins, S. (2003). Software for ecological and palaeoecological data analysis and visualization user guide version 1.5. Newcastle upon Tyne: Newcastle University. 
Kalff, J. (2002). Limnology: Inland water ecosystems. New Jersey: Prentice Hall.

Larsen, D. P., \& Mercier, H. T. (1976). Phosphorus retention capacity of lakes. Journal of the Fisheries Board of Canada, 33(8), 1742-1750. http://dx.doi.org/10.1139/f76-221

Levine, S. N., Lini, A., Ostrofsky, M. L., Bunting, L., Burgess, H., Leavitt, P. R., ... Gilles, E. (2012). The eutrophication of Lake Champlain's northeastern arm: Insights from paleolimnological analyses. Journal of Great Lakes Research, 38, 35-48. http://dx.doi.org/10.1016/j.jglr.2011.07.007

Li, B., Bi, J., \& Tian, Y. (2012). Effects of land use change on ecosystem service value in the heavy polluted area in Taihu basin. Scientia Geographica Sinica, 32(4), 471-476. http://dx.chinadoi.cn/10.13249/j.cnki.sgs.2012.04.011

Liu, E., Yang, X., Shen, J., Dong, X., Zhang, E., \& Wang, S. (2007). Environmental response to climate and human impact during the last 400 years in Taibai Lake catchment, middle reach of Yangtze River, China. Science of the Total Environment, 385(1), 196-207. http://dx.doi.org/10.1016/j.scitotenv.2007.06.041

Luoto, T. P., \& Ojala, A. E. (2014). Paleolimnological assessment of ecological integrity and eutrophication history for Lake Tiiläänjärvi (Askola, Finland). Journal of Paleolimnology, 51(4), 455-468. http://dx.doi.org/10.1007/s10933-014-9766-6

Ma, R., Yang, G., Duan, H., Jiang, J., Wang, S., Feng, X., ... Wu, J. (2011). China's lakes at present: Number, area and spatial distribution. Science China Earth Sciences, 54(2), 283-289. http://dx.doi.org/10.1007/s11430-010-4052-6

Qin, B., Xu, H., \& Dong, B. (2011). The priciple and practice of eutrophic lake restoration and management. Beijing: High Education Press.

Qin, B., Yang, L., Chen, F., Zhu, G., Zhang, L., \& Chen, Y. (2006). Mechanism and control of lake eutrophication. Chinese Science Bulletin, 51(19), 2401-2412. http://dx.doi.org/10.1007/s11434-006-2096-y

Rasmussen, P. (2005). Mid-to late-Holocene land-use change and lake development at Dallund S0, Denmark: vegetation and land-use history inferred from pollen data. The Holocene, 15(8), 1116-1129. http://dx.doi.org/10.1191/0959683605hl884rp

Sayer, C. D., Davidson, T. A., Jones, J. I., \& Langdon, P. G. (2010). Combining contemporary ecology and palaeolimnology to understand shallow lake ecosystem change. Freshwater Biology, 55(3), 487-499. http://dx.doi.org/10.1111/j.1365-2427.2010.02388.x

Smol, J. P. (1992). Paleolimnology: An important tool for effective ecosystem management. Journal of Aquatic Ecosystem Health, 1(1), 49-58. http://dx.doi.org/10.1007/BF00044408

Smol, J. P., \& Douglas, M. S. V. (1996). Long-term environmental monitoring in arctic lakes and ponds using diatoms and other biological indicators. Geoscience Canada, 23(4), 225-230.

Valkama, E., Uusitalo, R., Ylivainio, K., Virkajärvi, P., \& Turtola, E. (2009). Phosphorus fertilization: A meta-analysis of 80 years of research in Finland. Agriculture, Ecosystems \& Environment, 130(3), 75-85. http://dx.doi.org/10.1016/j.agee.2008.12.004

Ventelä, A.-M., Amsinck, S. L., Kauppila, T., Johansson, L. S., Jeppesen, E., Kirkkala, T., ... Sarvala, J. (2015). Ecosystem changes in large and shallow Lake Säkylän Pyhäjärvi, Finland, during the past $\sim 400$ years-Implications for management. Hydrobiologia, 1-22. http://dx.doi.org/10.1007/s10750-015-2552-2

Ventelä, A.-M., Kirkkala, T., Lendasse, A., Tarvainen, M., Helminen, H., \& Sarvala, J. (2011). Climate-related challenges in long-term management of Säkylän Pyhäjärvi (SW Finland). Hydrobiologia, 660(1), 49-58. http://dx.doi.org/10.1007/s10750-010-0415-4

Ventelä, A.-M., Tarvainen, M., Helminen, H., \& Sarvala, J. (2007). Long-term management of Pyhäjärvi (southwest Finland): Eutrophication, restoration-recovery? Lake and Reservoir Management, 23(4), 428-438. http://dx.doi.org/10.1080/07438140709354028

Vollenweider, R. A. (1968). Scientific fundamentals of the eutrophication of lakes and flowing waters, with particular reference to nitrogen and phosphorous as factors in eutrophication. Paris: Organization for Economic Co-operation and Development (OECD) Tech Rep. DAS/CSI/68.27.

Vose, R. S., Schmoyer, R. L., Steurer, P. M., Peterson, T. C., Heim, R., Karl, T. R., ... Eischeid, J. K. (2008). The global historical climatology network, GHCN: Long-term monthly temperature, precipitation, sea level pressure, and station pressure data, Version 2. Retrieved from http://cdiac.ornl.gov/ftp/ndp041/ndp041.pdf 
Wang, S., \& Dou, H. (1998). Lakes in China. Beijing: Science Press.

Weckström, J., Liao, M., Yu, G., Amsinck, S., Kauppila, T., Qin, B., ... Ventelä, A.-M. (2015). Responses of aquatic ecosystems to environmental changes in Finland and China. Frontiers in Ecology and Evolution (Accepted).

Wu, J., Huang, C., Zeng, H., Schleser, G. H., \& Battarbee, R. (2007). Sedimentary evidence for recent eutrophication in the northern basin of Lake Taihu, China: human impacts on a large shallow lake. Journal of Paleolimnology, 38(1), 13-23. http://dx.doi.org/10.1007/s10933-006-9058-x

Xie, H., Yu, X., \& Zhang, Y. (2001). Preliminary study on the coincident relationship between water environmental and human activity in Lake Taihu Basin. Resources and Environment in the Yangzi Basin, 10(5), 393-400.

Yang, G., Ma, R., Zhang, L., Jiang, J., Yao, S., Zhang, M., ... Zeng, H. (2010). Lake status, major problems and protection stragety in China. Journal of Lake Sciences, 22(6), 799-810.

Yang, M. (2013). The heritage and development of the featuring of Mosuo Traditional hourses in the Lugu Lake area-with the example of the planning and architectural design of the tourism service area of the Lugu Lake scenic (Master's Thesis, Kunming University of Science and Technology, Kunming, China). Retrieved from http://www.cnki.net/

Yu, G., Liao, M., \& Li, Y. (2013). Responses of lake ecosystem to the climate changes of the past 1000 years - Case study of dynamic simulations for ecosystem changes of Poyang Lake. Quaternary Sciences, 33(6), 1148-1159. http://dx.chinadoi.cn/10.3969/j.issn.1001-7410.2013.06.11

Yu, G., Xue, B., Lai, G. Y., Gui, F., \& Liu, X. M. (2007). A 200-yr historical modeling of catchment nutrient changes in Taihu basin, China. Hydrobiologia, 581(1), 79-81. http://dx.doi.org/10.1007/s10750-006-0514-4

Zhang, Y. (2014). The current water resources situation of Lugu Lake and countermeasures for sustainable management. Ningxia Journal of Agri. and Fores. Sci \& Tech., 55(3), 53-55.

\section{Copyrights}

Copyright for this article is retained by the author(s), with first publication rights granted to the journal.

This is an open-access article distributed under the terms and conditions of the Creative Commons Attribution license (http://creativecommons.org/licenses/by/3.0/). 